\title{
Efektivitas Pelaksanaan Mediasi Di Masa Pandemi Dalam Menekan Jumlah Angka Perceraian: Studi Kasus Pengadilan Agama Serang
}

\author{
Ahmad Harisul Miftah \\ UIN Sultan Maulana Hasanuddin Banten \\ Nurul Fazri \\ UIN Sultan Maulana Hasanuddin Banten
}

\begin{abstract}
Abstrak
Maraknya angka perceraian yang semakin tinggi dan terus bertambah apalagi di masa pandemi seperti ini, salah satunya disebabkan faktor ekonomi. Namun demikian, perkara perceraian tersebut harus sesuai dengan amanah Perma No.1 Tahun 2016 yang menyatakan pentingnya mediasi. Rumusan masalah dalam penelitian ini adalah: Bagaimana pelaksanaan mediasi di masa pandemi dalam penyelesaian perkara perceraian di Pengadilan Agama Serang?,Bagaimana peran hakim mediator dalam mendamaikan dan menekan jumlah angka perceraian pada masa pandemi di Pengadilan Agama Serang?, dan Bagaimana kendala yang dihadapi hakim mediator dalam mendamaikan perkara perceraian pada masa pandemi di Pengadilan Agama Serang?. Kesimpulan dari penelitian ini bahwa prosedur pelaksanaan mediasi di Pengadilan Agama Serang sudah sesuai dengan Perma No.1 Tahun 2016 tentang Prosedur Mediasi di Pengadilan dan juga menerapkan Protokol Kesehatan sesuai dengan Instruksi Presiden No. 6 Tahun 2020 tentang Peningkatan Disiplin dan Penegakan Hukum Protokol Kesehatan dalam Pencegahan dan Pengendalian Corona Virus Disease 2019, dan Hakim mediator berperan penting dalam mendamaikan dan menekan jumlah perceraian. Ini dapat dilihat pada laporan mediasi. Adapaun Kendala yang dihadapi hakim mediator terdiri dari beberapa faktor. Mulai dari faktor perkara perceraian, pihak yang berperkara dan faktor dari mediator itu sendiri.
\end{abstract}

Kata Kunci : Mediasi, Perceraian, Pandemi, Pengadilan Agama Serang

\section{Abtract}

The rise of divorce rates is getting higher and continues to grow especially in pandemic times like this, one of which is due to economic factors. However, the divorce case must be in accordance with the mandate of Perma No.1 of 2016 which states the importance of mediation. The formulation of the problems in this study is: How is the implementation of mediation in the pandemic period in the settlement of divorce cases in the Serang Religious Court?, How is the role of mediator judges in reconciling and reducing the number of divorce rates during the pandemic in the Serang Religious Court?, and What are the obstacles faced by mediator judges in reconciling divorce cases during pandemics in the Serang Religious Court?. The conclusion of this study is that the procedure for the implementation of mediation in the Serang Religious Court is in accordance with Perma No.1 of 2016 on Mediation Procedures in Court and also implements health protocols in accordance with Presidential Instruction No. 6 of 2020 on Improving Discipline and Law Enforcement of Health Protocols in the Prevention and Control of Corona Virus Disease 2019, and mediator judges play an important role in reconciling and suppressing the number of divorces. This can be seen in the mediation report. The obstacles faced by mediator judges consist of several factors. Starting from the factors of divorce cases, litigated parties and factors from the mediator itself.

Keywords: Mediation, Divorce, Pandemic, Religious Courts Attack 


\section{A. Pendahuluan}

Undang-Undang RI Nomor 1 tahun 1974 tentang Perkawinan Bab I Pasal 1, "Perkawinan ialah ikatan lahir bathin antara seorang pria dengan wanita sebagai suami istri dengan tujuan membentuk keluarga (rumah tangga) yang bahagia dan kekal berdasarkan Ketuhanan Yang Maha Esa". ${ }^{1}$

Realitas masyarakat dewasa ini, untuk menciptakan rumah tangga yang kekal dan bahagia sudah semakin sulit didapatkan, ini disebabkan maraknya angka perceraian yang semakin tinggi dan terus bertambah apalagi di masa pandemi seperti ini. Dari beberapa faktor yang menyebabkan terjadinya gugatan perceraian yaitu karena faktor ekonomi. Terbukti dari banyaknya kasus gugatan cerai yang banyak mengajukan gugatan cerai yang dipersidangkan di pengadilan. Pada bagian ini, hakim yang berwenang memberikan jawaban pada permasalahan tersebut dalam meja persidangan. Tetapi sebelum itu harus adanya upaya perdamaian antara kedua belah pihak yang sedang berperkara.

Akibat dari musibah pandemi yang sedang terjadi di Indonesia saat ini, banyak permasalahan-permasalahan yang terjadi, terkhusus dalam segi ekonomi. Dimana banyak para pekerja yang dirumahkan sementara atau bahkan yang tidak dipekerjakan lagi (PHK). Imbasnya, banyak para keluarga yang tadinya bekerja harus menganggur sedangkan kebutuhan hidup sebuah keluarga terus bertambah. Terjadilah kelumpuhan ekonomi, dimana mereka sulit untuk memenuhi kebutuhan hidup, sehingga akibatnya banyak menuai konflik di antara suami dan istri, bahkan permasalahan tersebut harus naik ke meja hijau.

Dikutip dari salah satu media massa yaitu Suara Banten, mengatakan bahwa, 2.000 suami istri di Serang, Banten bercerai selama pandemi corona sejak awal tahun 2020. Masalah ekonomi paling banyak di balik perceraian itu. Suami istri itu ada ada di wilayah Kabupaten dan Kota Serang mengajukan perceraian ke Pengadilan Agama Serang, Banten. Bahkan, Ketua Pengadilan Agama Serang, Banten, Dalih Effendy mengatakan, "Di masa pandemi covid-19 yang masih berlangsung. Ada kemungkinan angka perceraian bisa lebih meningkat di banding tahun 2019 yang menyentuh

1 Presiden Republik Indonesia, Undang-Undang Nomor 1 Tahun 1974 Tentang Perkawinan (Indonesia, 1974). 
angka 5000 pasangan". Bagaimana tidak tahun 2019 saja sejumlah 5000 pasangan suami istri yang bercerai, sedangkan bulan Juli tahun 2020 sudah 2000 pasangan yang bercerai, kemungkinan sampai akhir akan terus bertambah, apalagi dalam keadaan pandemi seperti ini. ${ }^{2}$ Isu yang diangkat dalam penelitian ini adalah seputar bagaimana pelaksanaan mediasi di masa pandemi dalam penyelesaian perkara perceraian di Pengadilan Agama Serang ? bagaimana peran hakim mediator dalam mendamaikan dan menekan jumlah angka perceraian pada masa pandemi di Pengadilan Agama Serang? bagaimana kendala yang dihadapi hakim mediator dalam mendamaikan perkara perceraian pada masa pandemi di Pengadilan Agama Serang?

Uraian mengenai kerangka pemikiran berisi tentang kerangka teori. Bahwa pelaksanaan mediasi merupakan cara penyelesaian sengketa melalui proses perundingan untuk memperoleh kesepakatan para pihak dengan bantuan mediator. Dalam teorinya proses mediasi dibagi kedalam tiga tahap, yaitu tahap pra mediasi, tahap pelaksanaan mediasi, dan tahap akhir implementasi mediasi. Ketiga tahap ini merupakan jalan yang akan di tempuh oleh mediator dan para pihak dalam menyelesaiakan sengketa mereka. ${ }^{3}$

Resolusi konflik dalam khazanah Islam khususnya ilmu fikih lebih dikenal dengan istilah sulh. Sulh adalah sebuah istilah penting baik dalam kosa kata hukum Islam maupun bahasa kebiasaan suku. Menurut syariat Islam, tujuan sulh adalah untuk mengakhiri konflik dan perselisihan sehingga mereka dapat menciptakan hubungan dalam kedamaian dan penuh persahabatan. Dalam hukum Islam, sulh adalah bentuk kontrak yang secara legal mengikat pada tingkat individu dan komunitas. Secara terminologis, istilah sulh digunakan dengan dua pengertian, yakni proses keadilan restoratif (restorative justice) dan penciptaan perdamaian serta hasil atau kondisi aktual yang dilahirkan oleh proses tersebut. ${ }^{4}$

\footnotetext{
2 Pebriansyah Ariefana, “2.000 Pasutri Di Serang Cerai Karena Suami Nganggur Selama Wabah Corona," Suarabanten.Id.

3 Syahrizal Abbas, Mediasi Dalam Hukum Syari'ah, Hukum Adat, Dan Hukum Nasional (Jakarta: Prenada Media Group, 2009).

4 Zakiyuddin Bhaidawi, Pendidikan Agama Berwawasan Multikultural (Jakarta: Erlangga, 2005).
} 


\section{B. Sejarah Pengadilan Agama Serang}

Dalam menyusun sejarah Pengadilan Agama Serang tidak ada satu dokumenpun yang dapat dijadikan rujukan untuk menentukan secara pasti kapan Pengadilan Agama Serang pertama kali dibentuk. Namun demikian, berbekal catatan Agus Chumaidy, BA (PYMT Ketua, periode 1976 - 1979 dan 1983 - 1988) dan untuk mendapatkan data yang akurat, peneliti pada waktu mewawancarai M. Syarbini Asy'ari dan Kiai Abdul Aziz.

Berdasarkan wawancara tersebut, tergambar sejarah pembentukan dan perkembangan Pengadilan Agama Serang, yang tidak lepas dari peran para Kiai dan Tokoh ulama Banten, dengan dibagi dalam beberapa periode sebagai berikut: 5

1. Periode pertama, tidak diketahui kapan Pengadilan Agama Serang dibentuk, diperkirakan tahun 1932. Ketua disebut penghulu landraad, yang diketuai oleh KH. Moch. Hasan atau yang disebut Ki Acang. Pada waktu itu, tidak ada Hakim Anggota, Panitera maupun karyawan. Tetapi untuk lokasi kantornya yaitu rumah penduduk di kampung Pegantungan (Sebelah utara Masjid Agung Ats-Tsauroh Serang).

2. Periode kedua tahun 1933 - 1938, yang diketuai oleh KH. R. Moch. Isa. Dan hakim anggotanya, KH. Moch. Soleman, KH. Moch. Djamhari dan KH. Moch. Hisni. Tidak ada panitera maupun karyawan. Tetapi untuk lokasi kantornya yaitu rumah penduduk di kampung Pegantungan (Sebelah utara Masjid Agung Ats-Tsauroh Serang).

3. Periode ketiga pada tahun 1938 - 1947, yang diketuai oleh KH. Moch. Yusran yang menggantikan KH. R. Moch.Isa yang mutasi ke MIT Jakarta. Untuk hakim anggotanya masih tetap sama yaitu KH. Moch. Soleman, KH. Moch. Djamhari dan KH. Moch. Hisni. Tidak ada panitera maupun karyawan. Tetapi untuk lokasi kantornya yaitu rumah penduduk di kampung Pegantungan (Sebelah utara Masjid Agung Ats-Tsauroh Serang).

\footnotetext{
5 Pengadilan Agama Serang, "Sejarah Pengadilan Agama Serang," Pengadilan Agama Serang (Serang, 2020), last modified 2020, accessed September 29, 2020, https:/ / paserang.go.id/index.php?pdlg=detail\&berita=1373.
} 
4. Periode keempat pada tahun 1947 - 1949, yang diketuai oleh KH. TB. Sholeh Ma'mun. Dan hakim anggotanya yaitu KH. Hisni, KH. Abdul Malik, KH. Masmun, KH. Misbah dan KH. Moch. Umar. Paniteranya yaitu M. Suradjaja dan tidak ada karyawan pada saat itu. Lokasi kantornya pada waktu itu, di serambi Masjid Agung Ats -Tsauroh Pegantungan Serang.

5. Periode kelima pada tahun 1949 - 1950, yang diketuai oleh KH. TB. Sholeh Ma'mun. Karena adanya agresi Belanda kedua, untuk sementara dijabat oleh KH. Marzuq. Dan hakim anggotanya yaitu KH. Hisni, KH. Abdul Malik, KH. Masmun, KH. Misbah dan KH. Moch. Umar. Paniteranya yaitu M. Suradjaja dan tidak ada karyawan pada saat itu. Lokasi kantornya di serambi Masjid Agung Ats -Tsauroh Pegantungan Serang.

6. Periode keenam pada tahun 1950 - 1951, yang diketuai oleh Kiai Sayuthi (Kependilan-Cilegon), selanjutnya Kiai Sayuthi digantikan oleh KH. Ali Misri. Dan hakim anggotanya yaitu KH. Hisni, KH. Abdul Malik, KH. Masmun, KH. Misbah dan KH. Moch. Umar. Paniteranya yaitu M. Suradjaja dan karyawannya bernama M. Syarbini Asy'ari. Lokasi kantornya di serambi Masjid Agung Ats -Tsauroh Pegantungan Serang.

7. Periode ketujuh tahun 1951 - 1962 yang diketuai oleh KH. Tb. Sholeh Ma'mun. Setelah Negara aman, ia kembali menjadi ketua pada tanggal 1 April 1951 sampai dengan akhir hayatnya tanggal 24 Mei 1962. Dan wakilnya pada saat itu, KH. Achmad Wardi Djamhari dan anggotanya yaitu $\mathrm{KH}$. Syamil (Kedung Kemiri-Cilegon), KH. M. Thahir, KH. Abdul Jabar (Cilegon), Kiai. M. Zainul Asyikin (Kelapa Dua-Serang), Kiai. M. Asjik (Lopang GedeSerang), KH. M. Thabrani (Pegantungan-Serang). Paniteranya M. Suradjaja (1950 - 1954), M. Usman Hadi (1954 - 1957), M. Syarbini Asy’ari (1957 - 1958), dan A. Syarbini. B. (1958 - 1961). Dan karyawannya, M. Shohib (1959 mutasi ke Pengadilan Agama Bandung), A. Muiz Ali (menantu KH. Tb. Sholeh Ma'mun yang kemudian non-aktif karena menjadi anggota DPRD TK I Jawa Barat), Tb. Mahdi Hasni (mutasi Hakim ke Pengadiln Agama Tangerang) dan yang terakhir Moch. Adjam. Untuk lokasi kantor tetap di serambi Masjid Agung Ats-Tsauroh Pegantungan, Serang. 
8. Periode kedelapan pada tanggal 1 Juli 1962 - 1 Juli 1963 yang diketuai oleh KH. A, Syadeli (Kaloran-Serang) dan wakilnya KH. Achmad Wardi Djamhari. Anggotanya yaitu KH. Syamil, KH. M. Thahir, KH. Abdul Jabar, KH. Zainul Asyikin, Kiai. M. Asjik dan KH. M. Thabrani. Paniteranya yaitu A. Syarbini. B dan karyawannya M. Syarbini Asy'ari. Moch. Adjam dan M. Syafuri. Lokasi kantor di rumah penduduk Kebon Jahe Serang.

9. Periode kesembilan pada tanggal 1 Juli 1963 - 1976, yang diketua oleh K. M. Zainul Asyikin dan wakil ketuanya K.M. Asjik (Lopang Gede-Serang). Pada tahun 1971 K.M. Asjik meninggal dunia, lalu digantikan oleh KH. Tb. Afif sampai dengan tahun 1975, karena beliau mutasi ke Pandeglang. Hakim anggota tetapnya K.M. Syam'un pada tahun 1974 sampai dengan tahun 1976, kemudian mutasi menjadi kepala KUA Kecamatan Cinangka dan $\mathrm{KH}$. Bahauddin Amin pada tahun 1965 sampai dengan tahun 1999. Hakim anggota lainnya (honor) yaitu KH. Syamil, KH. M. Thahir dan KH. M. Thabrani. Pada tahun 1969, hakim ahli tersebut diganti oleh KH. M. Rafe'i ( ayahanda Prof. Dr.Fauzul Iman, MA, yang sekarang menjabat Rektor UIN SMH Banten) dan Kiai Abdul Aziz. Paniteranya Tb. Abdul Latif (Lopang Cilik-Serang) pada tahun 1967-1968,kemudia di mutasi ke Kantor Departemen Agama Serang. Untuk karyawannya yaitu M. Syarbini Asy'ari, Moch. Adjam, M. Syafuri, Agus Chumaedy, BA, H.M. Hasanuddin dan Achmad Sururi. Lokasi Kantornya di rumah penduduk daerah Kebon Jahe Serang (1963-1966), Cipare Tegal, Serang (1965-1966) di kediaman M.Syarbini Asy'ari, Kelapa Dua (1966-1968) di kediaman K.M. Zainul Asyikin, tahun 1970 sampai dengan 1971 lokasinya di BKM Pisang Mas Serang, selanjutnya bulan Juni 1971 sampai dengan 4 Mei 1978 di Kandepag Jl. Kagungan No. 1 Kaloran Baru Serang, bergabung dengan KUA Pendais dan Penais pada waktu itu.

10. Periode kesepuluh pada tahun 1976 - 1979, diketuai oleh Agus Chumaidy, BA karena Kiai. M. Zainul Asyikin selaku ketua sebelumnya pensiun pada bulan Juli 1976. Hakim anggota tetapnya Drs. M. Alwi Syamsuddin dan KH. A. Bahauddin Amin, kemudian Hakim anggota (honor) pada saat itu, KH. Tb. 
Waseh, KH. M. Thabrani, KH. M. Rafe'I dan Kiai Abdul Aziz. Paniteranya ialah Wasik dan karyawannya M. Syarbini Asy'ari, Moch. Adjam, M.Moch. Sufni, HS. Lokasi kantornya yaitu di Jalan Vetersn No 31 B Telp. 81826 Serang (di lokasi tanah wakaf Masjid Agung Ats-Tsauroh Serang). Pada periode ini tahun 1977-1978 Pengadilan Agama Serang mendapatkan proyek bangunan gedung balai sidang, DIP Departemen Agama RI tertanggal 9 Maret 1977 Nomor: 100/XXVB/1977. Balai Sidang tersebut diresmikan oleh Menteri Agama RI pada saat itu yang bernama H. Alamsyah Ratu Perwira Negara pada hari Jum'at tanggal 5 Mei 1978, yang bertepatan dengan tanggal 27 Jumadil Akhir 1938 H.

11. Periode kesebelas pada tahun 1979 - 1981, yang diketuai oleh Drs.Oman Abdur Rahman (1 Pebruari 1979 sampai dengan 1 Maret 1981). Tanggal 1 Maret 1981 sampai dengan Desember 1981 di jabat sementara (PLT) oleh Agus Chumaedy BA, karena Drs. Oman Abdur Rahman di mutasi ke Pengadilan Tinggi Agama Bandung, Jawa Barat.

12. Periode keduabelas pada tahun 1981 - 1988 diketuai oleh Drs. Alwie Syamsuddin. Kemudian pada tahun 1984 Drs. Alwie syamsuddin mutasi ke Jambi. Dan dijabat sementara (PLT) oleh Drs. Agus Chumaedy, BA yang pada saat itu juga menjabat sebagai wakil ketua. Hakim anggota tetapnya yaitu A. Jahidi Hadi, BA dan KH. Bahauddin Amin. Hakim anggota (honor) yang lain yaitu KH. M. Rafe'i, KH. Abdul Aziz, KH. M. Thabrani, Drs. H. Rahmatullah N, A. Mabsyuti Syab, BA dan H. A. Busro Burhan. Paniteranya ialah Wasik, Kepala kepaniteraan Tata Usaha Fauziah SY Anasi BA, Kepala kepaniteraan perkara A. Tajuddin BA, Kepala Sub-Kepaniteraan bidang gugatan M. Syufni HS dan bidang permohonan M. Syafuri. Huku Syara, Stadok yaitu M. Syarbini Asy'ari, bidang kepegawaian Suhendy Haryatni BA, bagian umum M. Adjam, bagian keuangan Hanafi BA. Kemudian untuk bagian staff yaitu Abco Jailani BA, Achmad Sururi, E. Ali Mansur BA, Amung Kadawi, Hatibi BA, Makhum Mansur BA. Aliyah dan Abdullah Sahim. Lokasi kantornya yaitu di Jalan Vetersn No 31 B telp. 81826 Serang (di lokasi tanah wakaf Masjid Agung Ats-Tsauroh Serang). 
13. Periode ketiga belas pada bulan Desember 1988 - 1994 diketuai oleh Drs. Humaedi Husen. Dan memiliki Hakim agama yaitu A. Jahidi Hadi BA, KH. A. Bahauddin Amin, Dra. Nia Nurhamidah Romli, A. Damahuri Bandjar BA, E. Mudjaidi Amin BA, Ma'ani Aladdin BA, Drs. H. Rahmatullah N, A. Tajuddin BA dan Drs. A. Syahidi Misbach. Kemduian jabatan panitera sekaligus sekretarisnya Drs. H. A. Ridwan Arief, wakil pamiteranya Dra. H. Fauziyah Sy. Anasi, wakil sekretarisnya dijabat oleh Suhendy Haryatni. Kepala sub kepaniteraan bidang gugatan Makhtum Mansur BA dan bidang permohonan Abdullah BA. Bagian hukum syara stadok dijabat oleh M. Syufni HS, kepegawaian dijabat oleh M. Adjam, bagian umum dijabat oleh M. Syafuri dan bagian keuangan dijabat oleh E.Ali Mansur BA. Sedangakan jajaran staffnya yaitu Hatibi BA, Aswadi BA, Hulaesi SH, A. Sururi, Amung Kadawi, Hidayat, Hamid Safi BA. Untuk tempatnya atau lokasi kantornya masih sama seperti periode sebelumnya yaitu di Jalan Vetersn No 31 B Telp. 81826 Serang (di lokasi tanah wakaf Masjid Agung Ats-Tsauroh Serang).

14. Periode keempat belas yaitu tanggal 1 Maret 1994 - 28 Agustus 1994, yang ketuai oleh Moch. Soleh Kastiwa SH (yang pada tahun berikutnya mutasi ke Tasikmaaya). Wakil ketuanya dijabat oleh Drs.B Madjdudin (dari tahun 1996 - 1999), panitera sekaligus sekretaris dijbat oleh Drs. H.Ridwan Arief, wakil paniteranya Dra. H. Fauziyah, Sy. Anasi, wakil sekretarisnya Drs. Suhendy Haryatni. Sedangkan Untuk tempatnya atau lokasi kantornya masih sama seperti periode sebelumnya yaitu di Jalan Vetersn No 31 B Telp. 81826 Serang (di lokasi tanah wakaf Masjid Agung Ats-Tsauroh Serang). Pada periode ini Pengadilan Agama Serang mendapat bantuan dari Bupati Serang (Syukron Rosadi) sebesar Rp. 30.000.000,00 ( Tiga Puluh Juta Rupiah) untuk pembelian tanah yang dimiliki oleh Drs. Mas Hermani (Jakarta) seluas 2000 M2 yang terletak di Jalan Raya Petir Km. 3 Blok. Cibangke, Kelurahan Cipocok Jaya, Kecamatan Cipocok Jaya Serang seharga Rp. 20.000,00/meter, berarti total semua sebesar Rp. 40.000.000,00 dan kekurangannya sebesar Rp. 10.000.000,00 didapatkan dari hasil swadaya (iuran) pegawai Pengadilan Agama Serang 
pada saat itu. Tanah tersebut telah diterbitkan sertifikatnya Nomor: 9/2001 tanggal 06 - 02 - 2001 dan luas tanah dalam sertifkat tersebut 1994 M2.

15. Periode kelima belas 28 Agustus 1997 sampai dengan bulan Juli 2006. Pada periode ini ada tiga kali pergantian ketua, yang pertama Drs. Maftuh Abu Bakar S.H yang menjabat dari tanggal 28 Agustus 1997 sampai dengan tanggal 26 Desember 2001. Selanjutnya, H. Didin Fathuddin S.H, dari tanggal 26 Desember 2001 sampai dengan bulan Juli 2002. Dan yang terkahir diketuai oleh Drs. Mahmud Yunus bulan Juli 2002 sampai dengan 2006. Untuk wakil ketuanya pun sudah empat kali pergantian sampai tahun 2006, yang pertama di jabat oleh Drs. B. Madjduddin dari tahun 1996 sampai dengan 1999, yang kedua dijabat oleh Drs. H. Sam'un Abduh dari tahun 1999 sampai dengan bulan Juli 2002, yang ketiga dijabat oleh Drs.Enas Nasa'i SH dari bulan Juli 2002 sampai dengan awal tahun 2006 dan yang terkahir dijabat oleh Drs. Dudung Abdul Halim SH yang memulai dari tahun 2006. Untuk jabatan paniteranya yang pertama dijabat oleh Drs.H. A. Ridwan Arief dari tahun 1988 sampai dengan tanggal 26 Pebruari 1998, yang kedua dijabat oleh Drs. Thohirin Abdillah dari tanggal 26 Pebruari 1998 sampai dengan tanggal 02 Juni 2003 dan yang terkahir dijabat oleh Drs. Suhendy Haryatni pada tanggal 02 Juni 2003 sampai dengan tahun 2006. Wakil paniteranya dijabat oleh Drs.Hj. Fauziyah Sy Anasi dari tahun 1988 sampai dengan 1998 dan yang kedua dijabat oleh Drs. A. Bakhri Syams dari tahun 1998 sampai dengan 2001. Wakil sekretaris dijabat oleh Hulaesi SH dari tahun 1997 sampai dengan 1999, selanjutnya Dra. Futihat dri tahun 1999 sampai dengan bulan Maret 2003 dan terakhir Ratnasari Fitriyani SH dari bulan Maret 2003 sampai dengan tahun 2006. Pada periode ini dibangun kantor Pengadilan Agama Serang di Jalan Raya Petir Km.3 Cipocok Jaya Serang dan mulai ditempati pada tanggal 1 April 1998.6

\section{Perkembangan Mediasi di Pengadilan Agama Serang}


Dari data perkara perdata yang masuk selama tahun 2020 baik dari perkara gugatan maupun permohonan yaitu sebanyak 5.905 dan yang diputus oleh Hakim Pengadilan Agama Serang sebanyak 5.921 perkara. ${ }^{7}$ Sementara itu, mengenai laporan Mediasi Pengadilan Agama Serang dari bulan Maret sampai dengan bulan Desember sebanyak 858 perkara yang dimediasi, sebanyak 10 perkara yang berhasil dengan kesepakatan, 7 perkara yang berhasil dengan pencabutan, 20 perkara yang berhasil sebagian, 3 perkara yang tidak dapat dilaksanakan dan 323 perkara mediasi yang gagal dimediasi oleh hakim mediator Pengadilan Agama Serang di masa pandemi ini. ${ }^{8}$ Berdasarkan data perkara yang sudah diuraikan di atas, tingkat keberhasilan hakim mediator dalam memediasi kedua belah pihak yang berperkara sangatlah kecil, karena kebanyakan pasangan suami istri yang datang ke Pengadilan Agama Serang sudah bulat tekadnya untuk bercerai dengan pasangannya.

Mengenai efektivitas pelaksanaan mediasi di masa pandemi ini, hakim mediator tetap menerapkan kesehatan ketika sedang melaksanakan mediasi dengan belah pihak yang berperkara, terkadang ada saja memang ada sedikit kesulitan dalam berkomunikasi karena memakai masker dan menjaga jarak. Sehingga yang dibicarakannya ada yang kurang jelas. Selain itu kebanyakan pasangan suami istri yang menggugat perceraian adalah pihak perempuan (istri). Dan ketika ditanya oleh hakim mengenai alasannya sangat beragam, bukan hanya faktor ekonomi saja. Berdasarkan data temuan di lapangan ada beberapa faktor yang menjadi pemicu retaknya hubungan, mulai dari faktor perselisihan yang terus menerus yang menempati urutan tertinggi, kemudia faktor kekerasan dalam rumah tangga (KDRT), meninggalkan salah satu pihak, poligami, mabuk, judi, dihukum (penjara), dipaksa kawin dan murtad. ${ }^{9}$

D. Prosedur Pelaksanaan Mediasi Pada Masa Pandemi di Pengadilan Agama Serang

${ }^{7}$ Ahmad Harisul Miftah and Nurul Fazri, Wawancara Dengan Syahrul-Panitera Muda Hukum (Serang, 2021).

${ }^{8}$ Ahmad Harisul Miftah and Nurul Fazri, Wawancara Dengan Baehaki-Panitera (Serang, n.d.).

${ }^{9}$ Ahmad Harisul Miftah and Nurul Fazri, Wawancara Dengan Nurnaningsih- Hakim Pengadilan Agama Serang (Serang, n.d.). 
1. Pelaksanaan Mediasi pada Masa Pandemi dalam Penyelesaian Perkara Perceraian di Pengadilan Agama Serang

Proses mendamaikan para pihak yang berperkara atau bersengketa di Pengadilan yang disebut dengan mediasi merupakan salah satu proses penyelesaian sengketa yang sederhana, cepat dan biaya ringan (murah), sesuai dengan asas yang dimiliki oleh kekuasaan kehakiman yang tertuang dalam Pasal 2 ayat (4) Undang-undang No. 48 tahun 2009, karena dari asas tersebut bisa lebih efiesien dan efektif serta bisa dilakukan oleh masyarakat seluruh kalangan tanpa biaya yang mahal. Selain itu juga dapat memberikan akses penyelesaian yang lebih besar untuk menemukan penyelesaian yang memuaskan bagi para pihak dan tentunya mendapatkan rasa keadilan.

Mediasi adalah cara penyelesaian sengketa melalui proses perundingan untuk memperoleh kesepakatan para pihak dengan dibantu oleh pihak ketiga sebagai penengah yang disebut sebagai mediator. Sebelum kedua belah pihak ini (suami dan istri) bertemu di meja hijau atau meja persidangan, hakim pemeriksa perkara mewajibkan kedua belah pihak untuk menempuh jalur mediasi terlebih dahulu. Hal ini sesuai dengan amanah Peraturan Mahkamah Agung (PERMA) No. 1 Tahun 2016 Pasal 17 ayat (1) yang berbunyi “Pada hari sidang yang telah ditentukan dan dihadiri oleh para pihak, hakim pemeriksa perkara mewajibkan para pihak untuk menempuh mediasi."10 Yang disertai dengan adanya iktikad baik dari kedua belah pihak demi terselamatkannya bahtera rumah tangga dan tentunya untuk masa depan anak tercinta. Selain itu dijelaskan juga dalam ajaran Islam bahwa apabila ada persengketaan atau perselisihan sebaiknya melalui pendekatan "ishlah" karena itu asas kewajiban hakim mendamaikan bukan hanya tertuang dalam Pasal 65 dan 82 undang-undang No. 50 Tahun 2009 tetapi juga sesuai tuntunan ajaran Agama Islam. ${ }^{11}$

Latar belakang terjadinya virus Covid-19 ini terjadi Kota Wuhan, China yang awalnya terjadi di pasar hewan Huanan, yang menjual berbagai jenis daging

\footnotetext{
10 Mahkamah Agung RI, Peraturan Mahkamah Agung Nomor 1 Tahun 2016 Tentang Prosedur Mediasi Pengadilan (Republik Indonesia, 2016).

11 Sulaikin Lubis, Hukum Acara Peradilan Agama Di Indonesia (Jakarta: Kencana, 2005).
} 
binatang, termasuk yang tidak bisa dikonsumsi, seperti ular, kelalawar dan berbagai jenis tikus. Virus Covid-19 diduga dibawa kelalawar dan hewan lain yang dimakan manusia hingga terjadi penularan. Coronavirus sebetulnya tidak asing dalam dunia kesehatan hewan, tetapi hanya beberapa jenis yang mampu menginfeksi manusia hingga menjadi penyakit radang paru (pneumonia) hingga membuat kota Wuhan pada bulan Desember itu lumpuh karena banyak warga atau masyarakatnya yang terkena penyakit tersebut akibat penularan yang begitu cepat dan masif. ${ }^{12}$ Pada tanggal 11 April 2020, Organisasi Kesehatan Dunia (WHO) akhirnya menyatakan secara resmi virus Covid-19 sebagai pandemi, karena hampir seluruh Negara di dunia terjangkit virus ini, termasuk Negara Indonesia. Gejala ringan yang disebabkan oleh infeksi virus Covid-19 ini seperti batuk, letih, sesak nafas dan ngilu di seluruh tubuh dan juga demam. Ciri-ciri virus Covid-19 timbul setelah 2 sampai dengan 10 hari setelah kontak dengan virus tersebut. ${ }^{13}$ Sementara itu di Indonesia kasus ini pertama kali ditemukan pada dua warga Depok awal bulan Maret 2020. Data hingga hari sabtu 28 Maret 2020 jumlah warga yang positif terkena virus Covid-19 mencapai 1.155 dan 102 di antaranya meninggal dunia. ${ }^{14}$ Dengan adanya pernyataan resmi dari Organisasi Kesehatan Dunia (WHO) dan juga melihat banyaknya warga Indonesia yang terjangkit virus Covid-19 pemerintah merespon dengan cepat, termasuk dikeluarkannya Keputusan Presiden No. 12 Tahun 2020 tentang Penetapan Bencana Non-alam Penyebaran Corona Virus Disease 2019 (Covid-19) sebagai Bencana Nasional. ${ }^{15}$ Selain itu juga virus Covid-19 tersebut termasuk kedalam wabah penyakit menular yang termaktub dalam Undang-undang No. 4 Tahun 1984 tentang Wabah Penyakit Menular. Di dalam Pasal 1 poin a undangundang No.4 Tahun 1984 tersebut dijelaskan bahwa wabah penyakit menular yang selanjutnya disebut wabah adalah kejadian berjangkitnya suatu penyakit

\footnotetext{
12 Rosmha Widiyani, “Latar Belakang Vieus Corona, Perkembangan Hingga Isu Terkini,” News.Detik.Com, accessed April 29, 2020, https://news.detik.com/berita/d-4943950/latar-belakangvirus-corona-perkembangan-hingga-isu-terkini.

13 Ibid.

14 Ibid.

15 Keputusan Presiden No. 12 Tahun 2020 Tentang Penetapan Bencana Non-Alam Penyebaran Corona Virus Disease 2019 (Covid-19) Sebagai Bencana Nasional, n.d.
} 
menular dalam masyarakat yang jumlah penderitanya meningkat secara nyata melebihi dari keadaan yang lazim pada waktu dan daerah tertentu serta dapat menimbulkan malapetaka. ${ }^{16}$ Setelah itu Presiden juga mengeluarkan Inpres (Instruksi Presiden) No. 6 Tahun 2020 tentang Peningkatan Disiplin dan Penegakan Hukum Protokol Kesehatan dalam Pencegahan dan Pengendalian Corona Virus Disease 2019 (Covid-19) dalam rangka menjamin kepastian hukum, memperkuat upaya dan meningkatkan efektivitas pencegahan dan pengendalian Corona Virus Disease 2019 (Covid-19) di seluruh daerah di Indonesia. ${ }^{17} \mathrm{Hal}$ terebut pun direspon baik cepat oleh segala elemen pemerintahan, termasuk sejumlah kementrian dengan mengeluarkan Peraturan untuk diteruskan pada pemerintahan yang berada dibawahnya, dengan dikeluarkannya Peraturan Menteri Dalam Negeri (Permendagri) No. 20 Tahun 2020 tentang Percepatan Penanganan Corona Virus Disease 2019 di Lingkungan Pemerintah Daerah. ${ }^{18}$

Pengadilan Agama Serang dalam hal melaksanakan mediasi juga tidak terlepas dari peraturan yang telah ditetapkan oleh Pemerintah, baik Pemerintah Pusat sampai dengan Pemerintah Daerah. Dalam melaksanakan kinerjanya, Pengadilan Agama Serang tetap memperhatikan dan menerapkan protokol kesehatan secara ketat dan tegas agar tidak menimbulkan sumber penularan baru atau cluster baru pada tempat-tempat dimana terjadinya pergerakan orang, interaksi antar manusia dan juga berkumpulnya banyak orang dengan menerapkan perilaku disiplin $4 \mathrm{M}$, yaitu memakai masker, mencuci tangan, dan menjaga jarak serta menghindari kerumunan, karena Pengadilan Agama adalah salah satu tempat umum dimana banyak orang berlalu lalang atau berkerumun dan juga berinteraksi sehingga rentan adanya penyebaran virus covid-19. Hal tersebut sesuai dengan amanah Peraturan Walikota Serang No. 30 Tahun 2020 tentang Penerapan Disiplin dan Penegakan Hukum Protokol Kesehatan sebagai Upaya Pencegahan dan Pengendalian Corona Virus Disease 2019 (Covid-19)

\footnotetext{
16 Undang-Undang No. 4 Tahun 1984 Tentang Wabah Penyakit Menular, n.d.

17 Instruksi Presiden No. 6 Tahun 2020 Tentang Peningkatan Disiplin Dan Penegakan Hukum Protokol Kesehatan Dalam Pencegahan Dan Pengendalian Corona Virus Disease 2019 (Covid-19), n.d.

18 Peraturan Menteri Dalam Negeri (Permendagri) No. 20 Tahun 2020 Tentang Percepatan Penanganan Corona Virus Disease 2019 Di Lingkungan Pemerintah Daerah, n.d.
} 
yang dijelaskan dalam Bab III Pelaksanaan (Subjek Pengaturan) Pasal 3 poin a dan b, dimana poin a yaitu berbunyi "perorangan (melakukan $4 \mathrm{M}$, memakai masker, mencuci tangan, menjaga jarak dan menghindari kerumunan)" dan Pasal 3 poin b nya yang berbunyi, "pengelola, penyelenggara atau penanggung jawab tempat dan fasilitas umum (menyiapkan sarana dan prasarana $4 \mathrm{M}$ bagi karyawan dan pengunjung yang datang)". Dan juga dijelaskan dalam Pasal 4 yang berbunyi "subjek pengaturan yang dimaksud dalam Pasal 3 wajib melaksanakan dan mematuhi protokol kesehatan yang meliputi: ${ }^{19}$

1) Bagi perorangan:

a) Menggunakan alat pelindung diri berupa masker yang menutupi hidung dan mulut hingga dagu, jika harus keluar rumah atau berinteraksi dengan orang lain yang tidak diketahui kesehatannya;

b) Mencuci tangan secara teratur menggunakan sabun dengan air mengalir;

c) Pembatasan interkasi fisik (physical distancing); dan

d) Meningkatkan daya tahan tubuh dengan menerapkan perilaku hidup bersih dan sehat (PHBS).

2) Bagi pelaku usaha, pengelola, penyelenggara atau penanggungjawab tempat dan fasilitas umum:

a) Sosialisasi, edukasi dan penggunaan berbagai media informasi untuk memberikan pengertian dan pemahaman mengenai pencegahan dan pengendalian Covid-19;

b) Penyediaan sarana cuci tangan pakai sabun yang mudah diakses dan memenuhi standar atau penyediaan cairan pembersih tangan (hand sanitizer);

c) Upaya identifikasi (penapisan) dan pemantaun kesehatan bagi setiap orang yang akan beraktivitas di lingkungan kerja;

d) Upaya pengaturan jaga jarak;

\footnotetext{
19 Pemerintah Kota Serang, "Peraturan Walikota Serang Nomor 30 Tahun 2020 Tentang Penerapan Disiplan Dan Pengedalian Corona Virus Disease 2019," Https://Jdih.Serangkota.Go.Id, last modified 2020, accessed April 29, 2020, https://jdih.serangkota.go.id.
} 
e) Pembersihan dan diinfeksi lingkungan secara berkala;

f) Penegakan kedisiplinan pada perilaku masyarakat yang berisiko dalam penularan dan tertularnya Covid-19; dan

g) Fasilitas deketsi dini dalam penanganan kasus untuk mengantisipasi penyebaran Covid-19.

Dengan menerapkan prinsip atau perilaku disiplin yang tegas dan ketat tersebut, tentunya hakim dan jajaran pegawai Pengadilan Agama Serang memiliki andil yang besar dalam memutus mata rantai penyebaran virus covid19 dengan terus memberikan pemahaman dan sosialisasi kepada masyarakat yang yang berkunjung. Selain itu juga membantu tim medis, Pemerintah Pusat sampai kepada Pemerintah Daerah dan juga para relawan dari berbagai kalangan demi sembuhnya masyarakat Indonesia dari wabah penyakit menular (Virus Covid-19) yang sampai ini belum bisa diatasi secara komprehensif. Tentu perlu adanya peran dari berbagai pihak dalam memutus mata rantai ini dengan terus memberikan penyadaran kepada masyarat akan pentingnya menerapkan protokol kesehatan tersebut. Adapun analisis penerapan prosedur mediasi di Pengadilan Agama Serang sebagai berikut.

\section{a. Tahapan Pra Mediasi}

Pada hari persidangan yang telah ditentukan dan dihadiri oleh kedua belah pihak, majelis hakim Pengadilan Agama Serang menjelaskan kewajiban para pihak untuk menempuh proses mediasi dan keharusan adanya iktikad baik selama menempuh proses mediasi serta menjelaskan prosedur mediasi menurut Perma No. 1 Tahun 2016, dengan menerapkan protokol kesehatan kepada para pihak seperti memakai masker dan juga mencuci tangan terlebih dahulu dengan hand sanitizer yang telah disediakan. Hakim juga mengingatkan dan memberikan pemahaman para pihak akan pentingnya untuk menjaga kesehatan dan menerapkan protokol kesehatan. Setelah itu, ketua majelis mewajibkan pada hari itu juga atau 2 (dua) hari berikutnya kepada para pihak untuk memilih mediator yang dikehendaki bersama dan 
berunding tentang pembebanan biaya yang timbul jika memilih mediator non hakim. Untuk itu majelis hakim menskor persidangan.

Jika para pihak memilih hakim mediator, para pihak berhak memilih salah satu atau lebih mediator yang tertera di dalam daftar mediator. Hakim yang memeriksa perkara tidak boleh ditunjuk sebagai mediator kecuali dalam hal tidak dapat mediator lain. Setelah para pihak telah memilih mediator, ketua majelis hakim pemeriksa perkara menerbitkan penetapan yang memuat perintah untuk melakukan mediasi dan menunjuk mediator. Hakim pemeriksa perkara memberitahukan penetapan kepada mediator melalui panitera pengganti. Selanjutnya sidang ditunda untuk memberikan kesempatan menempuh proses mediasi. ${ }^{20}$

Dalam penjelasan di atas penerapan proses mediasi di Pengadilan Agama Serang sudah sesuai dengan apa yang ada dalam Perma No.1 Tahun 2016 tentang Prosedur Mediasi di Pengadilan. Sesuai dengan ketentuan Pasal 17 ayat (1) yang berbunyi : "Pada hari sidang yang telah ditentukan dan dihadiri oleh para pihak, hakim pemeriksa perkara mewajibkan para pihak untuk memepuh mediasi." Keharusan para pihak ini untuk menempuh proses mediasi dengan iktikad baik, dalam Pasal 7 ayat (1) dan ayat (2), menjelaskan bahwa, para pihak dan kuasa hukumnya wajib menempuh mediasi dengan iktikad baik. Salah satu pihak atau para pihak dan/atau kuasa hukumnya dapat dinyatakan tidak beriktikad baik oleh mediator dalam hal yang bersangkutan sebagai berikut:

1) Tidak hadir setelah dipanggil secara patut 2 (dua) kali berturut-turut dalam pertemuan mediasi tanpa alasan yang sah;

2) Menghadiri pertemun mediasi pertama, tetapi tidak pernah hadir pada pertemuan berikutnya meskipun telah dipanggil secara patut 2 (dua) kali berturut-turut tanpa alasan yang sah;

3) Ketidakhadiran berulang-ulang yang mengganggu jadwal pertemuan mediasi tanpa alasan yang sah; 
4) Menghadiri pertemuan mediasi tetapi tidak mengajukan dan/atau tidak menanggapi resume perkara pihak lain;

5) Tidak menandatangani konsep kesepakatan perdamaian yang telah disepakati tanpa alasan yang sah.

Dengan adanya iktikad baik inilah diharapkan proses mediasi akan berjalan dengan efektif dan efisien. Dan adanya akibat hukum dari pihak yang tidak beriktikad bak tersebut diharapkan tingkat keberhasilan mediasi semakin tinggi dan penumpukan perkara di Pengadilan secara bertahap bisa teratasi.

Kemudian ketentuan hak para pihak dalam memilih mediator diatur dalam Pasal 19 ayat (1) dan ayat (2) menjelaskan para pihak berhak memilih seorang atau lebih mediator yang tercatat dalam daftar mediator di Pengadilan. Jika dalam proses mediasi terdapat lebih dari satu orang mediator, pembagian tugas mediaor ditentukan dan disepakati oleh para mediator.

b. Pelaksanaan Mediasi

Dalam waktu paling lama 5 (lima) hari terhitung sejak penetapan mediator, para pihak dapat menyerahkan resume perkara kepada mediator. Mediasi dilaksanakan di ruang mediasi Pengadlan Agama Serang atau di tempat lain di luar Pengadilan yang disepakati oleh para pihak apabila mediator bukan dari hakim. Mediator non hakim dan bukan pegawai Pengadilan yang dipilih atau ditunjuk bersama-sama dengan mediator hakim atau pegawai Pengadilan dalam satu perkara wajib menyelenggarakan mediasi yang bertempat di Pengadilan. Proses mediasi berlangsung paling lama 30 (tiga puluh) hari terhitung sejak penetapan perintah melakukan mediasi atas persetujuan bersama dapat diperpanjang 30 (tiga puluh) hari. Dan atas persetujuan para pihak dan/atau kuasa hukum, mediator dapat mengahdirkan seorang atau lebih ahli, tokoh masyarakat, tokoh agama atau tokoh adat.

Sebelum pelaksanaan mediasi itu dimulai, mediator memastikan para pihak untuk menerapkan protokol kesehatan terlebih dahulu agar pada saat 
dilaksanakannya mediasi, para pihak yang ada diruangan tersebut sudah steril dan tidak menjadi pemicu penyebaran cluster baru virus Covid-19. Setelah itu mediator mediator melakukan hal-hal di antaranya sebagai berikut:

1) Memperkenalkan diri dan memberikan kesempatan kepada para pihak untuk saling memperkenalkan diri;

2) Menjelaskan kedudukan dan peran mediator yang netral dan tidak mengambil keputusan;

3) Menyusun jadwal mediasi berdasarkan kesepakatan;

4) Memberikan kesempatan kepada para pihak untuk menyampaikan permasalahan dan usulan perdamaian;

5) Mencari berbagai pilihan dan penyelesaian yang terbaik bagi para pihak.

Dalam hal kedua belah pihak tidak hadir maka mediasi ditunda untuk memanggil para pihak. Apabila telah dipanggil 2 (dua) kali berturut-turut tidak hadir tanpa alasan yang sah, tidak menanggapi atau mengajukan resume dan tidak mendatangani konsep kesepakatan perdamaian dapat dinyatakan tidak beriktikad baik oleh mediator dalam hal yang bersangkutan, maka mediator menyatakan mediasi gagal.

Proses mediasi diawali dengan identifikasi masalah. Untuk itu mediator memberi kesempatan kepada kedua belah pihak yang hadir untuk menyiapkan resume perkara baik secara lisan maupun tertulis. Dan jika diperlukan bisa mendatangkan para ahli atau tokoh masyarakat atas kesepakatan para pihak untuk dimintai pendapat atau mencari solusi terbaik bagi para pihak guna tercapainya kesepakatan damai. Setelah mengdentifikasi permasalahan dan alternatif penyelesaian yang disampaikan kedua pihak, mediator menawarkan kepada pihak tergugat alternatif solusi yang diajukan penggugat dan sebaliknya, untuk pendapat atau keterangan. Jika pelaksanaan mediasi tidak memungkinkan kedua belah pihak untuk dihadirkan secara bersama karena akan dikhawatirkan memperparah 
perselisihan, maka hakim bisa memediasi para pihak secara bergantian dalam menyampaikan resume perkara baik secara lisan maupun tulisan. Setelah itu jika para pihak sudah memungkinkan untuk dihadirkan secara bersama, maka mediator menjadwalkan kapan akan dilaksanakan lagi mediasi lanjutan, dengan catatan para pihak bisa tenang pada saat berlangsungnya mediasi. $^{21}$

Dalam pelaksanaan mediasi di atas, waktu mediasi juga sejalan dengan Pasal 24 ayat (1), (2) dan (3) yang menrangka dalam waktu paling lama 5 (lima) hari terhitung penetapan mediasi para pihak dapat menyerahkan resume perkara kepada pihak lain dan mediator. Proses mediasi paling lama 30 (tiga puluh) hari terhitung sejak penetapan perintah melakukan mediasi. Dan atas dasar kesepakatan para pihak, jangka waktu mediasi dapat diperpanjang paling lama 30 (tiga puluh) hari terhitung sejak berkahir jangka waktu penetapan perintah melakukan mediasi. Pengaturan waktu mediasi ini lebih singkat dengan ketentuan yang terdapat dalam Perma No.1 tahun 2008 yang mengatur jadwal mediasi dalam 40 (empat puluh) hari. Namun perpanjangan waktu untuk mediasi atas kesepakatan para pihak lebih lama lagi yaitu 30 (tiga puluh) hari, sedangkan dalam Perma No.1 Tahun 2008 hanya 14 (empat belas) hari. Walaupun dalam kenyataanya waktu mediasi tidak sampai 30 (tiga puluh) hari, karena memang sifatnya kondisional tergantung kesepakatan para pihak. Dan di dalam Pasal 6 ayat (1) dan (2) atas persetujuan para pihak dan / atau kuasa hukum mediator dapat menghadirkan seorang atau lebih ahli, tokoh masyarakat, tokoh agama atau tokoh ahli guna menjunjang proses mediasi di Pengadilan. Selain itu juga pelaksanaan mediasi di Pengadilan Agama Serang sudah menerapkan protokol kesehatan pada saat para pihak dimediasi. Hal ini sudah sesuai dengan peraturan yang sudah ditetapkan pemerintah dalam hal ini Peraturan Walikota Serang No. 30 Tahun 2020 tentang Penerapan Disiplin dan Penegakan Hukum Protokol Kesehatan sebagai Upaya Pencegahan dan Pengendalian Corona Virus Disease 2019 (Covid-19) yang dijelaskan dalam 
Bab III Pelaksanaan (Subjek Pengaturan) Pasal 3 poin a dan b, dimana poin a yaitu berbunyi "perorangan (melakukan $4 \mathrm{M}$, memakai masker, mencuci tangan, menjaga jarak dan menghindari kerumunan)" dan Pasal 3 poin b nya yang berbunyi, "pengelola, penyelenggara atau penanggung jawab tempat dan fasilitas umum (menyiapkan sarana dan prasarana $4 \mathrm{M}$ bagi karyawan dan pengunjung yang datang)".

\section{c. Laporan Mediasi}

Jika mediasi mencapai kesepakatan atau kesepakatan perdamaian sebagian, para pihak dengan bantuan mediator wajib merumuskan kesepakatan tersebut secara tertulis dalam kesepakatan perdamaian yang ditandatangani oleh para pihak dan mediator. Setelah kesepakatan tersebut disetujui dan ditandatangani para pihak dan mediator, mediator wajib melaporkan secara tertulis keberhasilan mediasi kepada majelis hakim.

Sedangkan dalam hal tidak diperoleh kesepakatan, mediator menyatakan proses mediasi gagal, mediator memberitahukannya secara tertulis kepada hakim pemeriksa perkara. Setelah menerima pemberitahuan tersebut, hakim pemeriksa perkara segera menerbitkan penetapan untuk melanjutkan perkara lewat persidangan. ${ }^{22}$

Sama seperti halnya dengan yang diatur dalam Perma, apabila mediasi mencapai kesepakatan dalam Pasal 27 ayat (1) menjelaskan, para pihak dengan bantuan mediator, wajib merumuskan kesepakatan secara tertulis dalam kesepakatan perdamaian yang ditandatangani oleh para pihak dan mediator. Jika tercapai kesepakatan perdamaian atau berhasil sebagian Pasal 29 ayat (2) menjelaskan perdamaian sebagian dibuat dan ditandatangani oleh penggugat dengan sebagian pihak tergugat yang mencapai kesepakatan dan mediator. Dalam hal proses mediasi mencapai kesepakatan antara penggugat dan sebagian pihak tergugat, penggugat mengubah gugatan dengan tidak lagi mengajukan pihak tergugat yang tidak mencapai kesepakatan sebagai pihak lawan. Jika mediasi gagal, dalam Pasal 32 ayat (1), mediator wajib 
menyatakan mediasi tidak berhasil mencapai kesepakatan dan memberitahukan kepada secara tertulis kepada hakim pemeriksa perkara.

Dari penerapan tahapan proses mediasi di Pengadilan Agama Serang yang sudah dijelaskan di atas, secara garis besar proses penerapan atau prosedur pelaksanaan mediasi sudah sesuai dengan apa yang ada di dalam Perma No.1 Tahun 2016 tentang Prosedur Mediasi di Pengadilan, pada masa pandemi ini dengan tentunya memperhatikan dan menerapakan protokol kesehatan agar tidak terjadi penyebaran cluster baru virus Covid-19 sesuai dengan peraturan yang sudah ditetapkan oleh pemerintah. Hanya saja dalam hal waktu mediasi 30 (tiga puluh) hari tidak diterapkan secara utuh, ini dikarenakan di sisi lain Peradilan menganut asas cepat, sederhana dan biaya ringan yang tujuan utamanya mengurangi penumpukan perkara yang ada di Pengadilan. Dulu sebelum diterbitkannya Perma No. 1 Tahun 2016 Pengadilan Agama Serang pernah mempunyai kebijakan mengeneralisasikan semua kasus perkara yang dimediasi menunggu sampai waktu 40 (empat puluh) hari. ${ }^{23}$ Namun dapat dari kebijakan tersebut adalah semakin menumpuknya perkara di Pengadilan Agama Serang. Sehingga kebijakan tersebut akhirnya diubah, yang dulunya menunggu sampai waktu 40 (empat puluh) hari sekarang waktu mediasi di Pengadilan Agama Serang sifatnya kondisional tergantung kesepakatan para pihak dalam proses mediasi. Di masa pandemi ini angka perceraian di Pengadilan Agama Serang memang semakin meningkat dibandingkan sebelum masa pandemi terjadi. Pihak yang mengajukan gugatan perceraian didominasi pihak istri dan meningkatnya angka perceraian disebabkan oleh banyak faktor salah satunya faktor ekonomi, sehingga menimbulkan perselisihan secara terus menerus karena banyak para suami yang di putus kerja (PHK) oleh suatu perusahaan atau tempat kerjanya. Selain itu juga pertengkaran atau perselisihan terjadi karena adanya perselingkuhan yang dilakukan pihak suami sehingga membuat pertengkaran hebat yang berujung pada gugatan perceraian di Pengadilan. Pengadilan Agama Serang mencatat adat 3.304 pasangan suami istri di 
Kabupaten dan Kota Serang selama tahun 2020. Jelas adanya peningkatan angka perceraian yang terjadi pada tahun 2019 yang hanya berkisar 3.000 dan pada tahun 2018 sebanyak 2.472 pasangan suami istri. ${ }^{24}$

2. Peran Hakim Mediator dalam Mendamaikan dan Menekan Jumlah Angka Perceraian pada Masa Pandemi di Pengadilan Agama Serang

Sebelum proses pemeriksaan di Pengadilan dimulai, hakim yang memeriksa perkara wajib untuk mendamaikan para pihak yang berperkara atau bersengketa. Proses mediasi ini wajib diikuti oleh setiap hakim, mediator, para pihak dan/atau kuasa hukum. Semua sengketa perdata wajib melalui proses mediasi, bukan hanya sengketa perdata biasa saja, namun perkara perlawanan (verzet) atas putusan verstek dan perlawanan pihak berperkara (partij verzet) maupun pihak ketiga (derden verzet) teehadap pelaksanaan putusan yang berkekuatan hukum tetap. Walaupun dikatakan bahwa semua sengketa yang masuk harus melalui proses mediasi, terdapat beberapa sengketa yang dikecualikan dari kewajiban penyelesaian melalui mediasi dan diatur dalam Pasal 4 ayat (2) dan (4) Perma No. 1 Tahun 2016 yang berbunyi, “Sengketa yang dikecualikan dari kewajiban penyelesaian melalui mediasi sebagaimana dimaksud pada ayat (1) meliputi:

1) Sengketa yang pemeriksaannya persidangan ditentukan tenggang waktu penyelesaiannya meliputi antara lain:

a) Sengeketa yang diselesaikan melalui prosedur Pengadilan Niaga;

b) Sengketa yang diselesaikan melalui prosedur Pengadilan Hubungan Industrial;

c) Keberatan atas putusan Komisi Pengawas Persaingan Usaha;

d) Keberatan atas putusan Badan Penyelesaian Sengketa Konsumen;

e) Permohonan pembatalan putusan arbitrase;

f) Keberatan atas putusan Komisi Informasi;

g) Penyelesaian perselisihan Partai Politik;

h) Sengeketa yang diselesaikan melalui tata cara gugatan sederhana; dan 
i) Sengketa lain yang pemeriksaannya di persidangan ditentukan tenggang waktu penyelesaiannya dalam ketentuan peraturan perundang-undangan.

2) Sengeketa yang pemeriksaanya dilakukan tanpa hadirnya penggugat atau tergugat yang telah dipanggil secara patut;

3) Gugatan balik (rekonvensi) dan masuknya pihak ketiga dalam suatu perkara (intervensi);

4) Sengketa mengenai pencegahan, penolakan, pembatalan dan pengesahan perkawinan;

5) Sengketa yang diajukan ke Pengadilan setelah diupayakan penyelesaian di luar Pengadilan melalui Mediasi dengan bantuan Mediator bersertifikat yang terdaptar di Pengadilan setempat tetapi dinyatakan tidak berhasil berdasarkan pernyataan yang ditandatangani oleh para pihak dan Mediator bersertifikat.

Kemudian Pasal 4 ayat (4) menjelaskan bahwa, berdasarkan kesepakatan para pihak, sengketa yang dikecualikan kewajiban Mediasi sebagaimana dimaksud pada ayat (2) huruf a, huruf c dan huruf e tetap dapat diselesaikan melalui Mediasi sukarela pada tahap pemeriksaan perkara dan tingkat upaya hukum.

Apabila hakim yang memeriksa perkara tidak memerintahkan para pihak yang berperkara untuk menempuh proses Mediasi maka dapat dikatakan bahwa telah terjadi pelanggaran terhadap peraturan perundang-undangan yang mengatur mengenai Mediasi di Pengadilan.

Di bawah ini merupakan laporan jumlah perkara perdata yang diterima dan diputus oleh Pengadilan Agama Serang dari tahun 2018 sampai dengan tahun 2020: 25

\begin{tabular}{|c|c|c|c|c|c|}
\hline \multirow{2}{*}{ No } & \multicolumn{2}{|c|}{ Tahun } & \multicolumn{2}{c|}{ Permohonan } \\
\cline { 3 - 5 } & & Masuk & Putus & Masuk & Putus \\
\hline
\end{tabular}

${ }_{25}$ Ahmad Harisul Miftah and Nurul Fazri, Wawancara Dengan Afiah-Panitera Muda Hukum Pengadilan Agama Serang (Serang, n.d.). 


\begin{tabular}{|c|c|c|c|c|c|}
\hline 1 & 2018 & 2.806 & 2.700 & 2.311 & 2.315 \\
\hline 2 & 2019 & 3.166 & 3.363 & 2.580 & 2.584 \\
\hline 3 & 2020 & 3.399 & 3.397 & 2.506 & 2.524 \\
\hline
\end{tabular}

Dari data laporan jumlah perkara di atas yang masuk dari tahun 2018 sampai dengan tahun 2020 baik perkara gugatan maupun permohonan yaitu adanya peningkatan kasus tiap tahunnya. Tentunya hal ini menunjukan bahwa terus adanya peningkatan kasus perkara yang terjadi di Pengadilan Agama Serang dari tahun 2018 sampai dengan tahun 2020 dengan beragam faktor perceraian yang melatarbelakanginya, mulai dari perselisihan secara terus menerus, meninggalkan salah satu pihak, ekonomi, kekerasan dalam rumah tangga (KDRT), mabuk, judi, poligami, kaiwn paksa dan murtad. Selain itu mirisnya dengan meningkatnya angka perceraian perceraian yang terjadi pada masa pandemi di Pengadilan Agama Serang pada tahun 2020 itu sejumlah 3.304 pasangan suami istri yang bercerai. Tentunya ada perbedaan yang signifikan antara tahun 2019 sebelum masa pandemi yang hanya berkisar 3.000 dan tahun 2018 yang berkisar 2.310 kasus perceraian yang terjadi dan yang mengajukan gugatan kebanyakan pihak istri. Hal ini membuktikan bahwa masa pandemi ini memberikan dampak negatif terhadap keharmonisan sebuah keluarga sehingga menyebabkan perselisihan yang terus menerus. Apalagi masa pandemi ini tidak bisa diprediksi kapan akan berhenti, tentunya yang dikhawatirkan angka perceraian akan terus meningkat. Berikut di bawah ini Laporan Mediasi di Pengadilan Agama Serang dari tahun 2018 sampai dengan tahun 2020 :

\begin{tabular}{|c|c|c|c|c|c|c|c|}
\hline & & \multirow{2}{*}{$\begin{array}{c}\text { Jumlah } \\
\mathrm{N}\end{array}$} & Tahu & \multicolumn{5}{|c|}{ Penyelesaian Mediasi } \\
\cline { 4 - 8 } o & $\begin{array}{c}\text { Perkara } \\
\text { yang di }\end{array}$ & $\begin{array}{c}\text { Medias } \\
\text { i }\end{array}$ & $\begin{array}{c}\text { Berhasil } \\
\text { dengan } \\
\text { Kesepakata } \\
\mathrm{n}\end{array}$ & $\begin{array}{c}\text { Berhasil } \\
\text { dengan } \\
\text { Pencabuta } \\
\mathrm{n}\end{array}$ & $\begin{array}{c}\text { Berhasil } \\
\text { dengan } \\
\text { Sebagia } \\
\mathrm{n}\end{array}$ & $\begin{array}{c}\text { Tidak } \\
\text { Berhasi } \\
1\end{array}$ & $\begin{array}{c}\text { Tidak dapat } \\
\text { Dilaksanaka } \\
\mathrm{n}\end{array}$ \\
\hline 1 & 2018 & 994 & 11 & 13 & 28 & 335 & 31 \\
\hline 2 & 2019 & 1.017 & 6 & 7 & 12 & 368 & 48 \\
\hline 3 & 2020 & 1.018 & 10 & 8 & 21 & 385 & 3 \\
\hline
\end{tabular}


Dari laporan perkara mediasi di atas menunjukan bahwa adanya peningkatan jumlah perkara yang dimediasi setiap tahunnya dan hasil penyelesaian mediasinya pun sangat beragam. Tetapi jika dilihat berdasarkan data tingkat kegagalan mendamaikan dari tahun 2018 sampai dengan tahun 2020 terus adanya peningkatan, walaupun tidak begitu signifikan perbedaannya antara sebelum masa pandemi dan masa pandemi. Hal ini tentunya harus menjadi sebuah evaluasi hakim mediator Pengadilan Agama Serang dalam menekan jumlah angka perceraian yang terjadi di Serang, mengingat peranan hakim sangat krusial dalam mendamaikan pihak yang berselisih tersebut. Hakim dituntut harus mengetahui dan memahami faktor-faktor penyebab dari perselisihan dan pertengkaran itu. Apabila hal ini sudah diketahui oleh hakim, maka dengan mudah hakim dapat mengajak dan mengarahkan para pihak yang berselisih itu untuk berdamai dan rukun kembali seperti sedia kala. Para hakim harus terpanggil hatinya untuk mengusahakan perdamaian secara optimal, tidak hanya terjebak pada usaha mencari fakta kualitas perselisihan itu sendiri sedangkan ia tidak mengetahui faktor yang melatarbelakangi pertengkaran itu. Apalagi kalau para hakim dalam mengusahakan perdamaian itu hanya sekadar menjalankan formalitas belaka dan hanya memakan waktu beberapa menit saja, sehingga upaya perdamaianpun jauh dari kata optimal dan mendatangkan hasil yang memuaskan bagi para pihak.

Selain itu juga khusus dalam perkara perdamaian, asas dalam mendamaikan para pihak adalah bersifat imperatif. Usaha mendamaikan merupakan beban yang diwajibkan oleh hukum kepada para hakim dalam setiap memeriksa, mengadili dan memutus dan perkara perceraian. Oleh karena itu, upaya mendamaikan dalam perkara perceraian atas dasar perselisihan dan pertengkaran secara terus menerus haruslah dilakukan oleh hakim secara optimal.

3. Kendala yang Dihadapi Hakim Mediator dalam Mendamaikan Perkara Perceraian pada Masa Pandemi di Pengadilan Agama Serang 
Apabila melihat dari efektivitas hakim mediator Pengadilan Agama Serang dalam mendamaikan para pihak yang berselisih atau bersengketa, tentunya tidak sesuai dari apa yang diharapkan berdasarkan data telah dilihat dan juga belum sesuai dengan harapan Perma No.1 Tahun 2016. Ini menjadi hal yang sangat miris karena jumlah angka perceraian dari awal masa pandemi ini terus meningkat dratis, artinya Pengadilan Agama Serang dalam hal ini sebagai eksekutor dalam menjalankan Perma tersebut, belum mampu menjawab segala permasalahan perdata khususnya dalam perkara perceraian yang ada di Serang.

Jika dilihat secara objektif memang sangat berat beban yang diterima oleh Pengadilan Agama Serang dalam mendamaikan perkara perceraian, mengingat masa pandemi yang sedang terjadi sehingga membatasi segala ruang gerak hakim mediator dalam mendamaikan para pihak tersebut. Belum lagi menumpuknya perkara yang terjadi dari bulan sebelumnya dan dibatasinya jumlah persidangan setiap harinya agar tidak mengakibatkan antrean yang panjang yang mengkhawatirkan terjadi penyebaran atau penularan cluster baru virus covid-19 yang belum berakhir sampai sekarang.

Kendala yang dihadapi hakim mediator dalam mendamaikan para pihak didominasi oleh faktor internal, seperti faktor perkara perceraian, pihak yang berperkara dan juga faktor mediator itu sendiri.

a. Faktor Perkara Perceraian

Faktor perkara perceraian adalah landasan awal untuk mengambil langkah bercerai dan mengajukan gugatan atau permohonan cerai ke Pengadilan Agama. Perkara tersebut seperti: 26

1) Konflik yang terjadi sudah lama dan berlarut-larut. Karena konflik sudah sangat lama, maka tidak mau lagi mendengar masukanmasukan dari pihak lain termasuk dari pihak mediator;

2) Masalah yang dialami para pihak adalah masalah yang unik yang menyangkut dan psikologis, maka sukar sekali mendamaikannya, apalagi masalahanya sudah berlangsung lama dan sudah bertumpuk dengan masalah lain; 
3) Berat dan ringannya perkara yang dialami pula turut menjadi faktornya. Seperti bercerai karena faktor perselingkuhan dan faktor ekonomi.

b. Faktor Pihak yang Berpekara

Faktor ini menjadi faktor paling dominan yang menjadi penyebab kegagalan proses mediasi di Pengadilan Agama Serang. Seperti adanya keinginan kuat para pihak untuk bercerai. Umumnya kegagalan mediasi karena para pihak sudah memiliki keinginan kuat untuk bercerai dan telah gagal melakukan perdamaian yang dilakukan secara kekeluargaan. Sebelum pihak perkara mengajukan gugatan atau permohonan cerai ke Pengadilan Agama biasanya ada yang sudah melalui tahap perdamaian secara kekeluargaan. Tidak tercapainya perdamaian dengan cara musyawarah (kekeluargaan) menjadi faktor sulitnya hakim mediator dalam mendamaikan para pihak. ${ }^{27}$

c. Faktor dari Mediator

1) Mediator berasal dari unsur hakim. Karena mediator dari unsur hakim, maka mediator sering terjebak dan sulit memposisikan dirinya antara sebagai mediator dan juga hakim.

2) Tidak adanya mediator dari luar Pengadilan yang memiliki waktu panjang dan dapat membantu proses mediasi dengan maksimal.

Selain dari pada kendala yang sudah dijelaskan diatas, ada kendala lain yang dihadapi hakim pada saat pelaksanaan mediasi di masa pandemi ini, seperti penggunaan masker pada saat komunikasi dengan para pihak sehingga menyebabknya sedikit ketidakjelasan dalam berkomunikasi. ${ }^{28}$

Jika ditinjau dari teori kefektifan suatu hukum, tentu perma ini belum efektif dilaksanakan di lapangan, baik oleh mediator selaku pihak ketiga dan juga para pihak yang berpekara kebanyakan belum sadar akan pentingnya perdamaian. Tentunya hal ini menjadi hal yang sangat 
miris ketika suatu hukum belum bisa ditegakan karena ada beberapa faktor yang belum terpenuhi. Termasuk tingkat kesadaran masyarakat yang masih rendah sehingga penegakan hukum ini sangat sulit untuk ditegakan dan diterapkan. Jika dikaitakan dengan tiga unsur sistem hukum, yaitu struktur hukum (legal struktur), substansi hukum (legal substance) dan budaya hukum (legal culture) tidak memenuhi klasifikasi yang terdapat dalam ketiga unsur tersebut. Terutama unsur budaya hukum yang merupakan faktor yang paling dominan yang menghambat efektivitas keberhasilan mediasi sesuai dengan Perma No.1 Tahun 2016. Selain itu, suatu aturan harus dalam keadaan valid terlebih dahulu baru diketahui apakah aturan tersebut dapat menjadi efektif. Jika setelah diterapkan ternyata peraturan yang sebenarnya sudah valid tersebut ternyata tidak dapat diterapkan atau tidak diterima oleh masyarakat secara meluas dan atau secara terus menerus, maka ketentuan tersebut menjadi hilang unsur validitasnya, sehingga berubah sifat dari aturan yang valid menjadi aturan yang tidak valid.

Sementara itu pelaksanaan mediasi di Pengadilan Agama Serang tidak jauh berbeda dari sebelum terjadinya pandemi, yang memebedakan hanyalah penerapan protokol kesehatan sesuai yang dianjurkan dan ditekankan oleh pemerintah agar bisa memutus mata rantai Covid-19 di Indonesia. Tetapi ada efek atau pengaruh yang disebabkan oleh terjadinya pandemi ini yaitu dengan meningkatnya angka perceraian dari sebelum masa pandemi. Tentunya dalam hal ini mediator Pengadilan Agama Serang belum mampu mendamaikan para pihak yang berperkara khususnya perkara perceraian yang teru meningkat dari tahun 2018 sampai dengan tahun 2020 masa pandemi sekarang. Hal ini menunjukan adanya peningkatan angka perceraian antara sebelum masa pandemi (tahun 2018 dan 2019) dan juga masa pandemi tahun 2020. Sehingga ini menjadi pekerjaan rumah bagi mediator Pengadilan Agama Serang kedepannya dalam menekan jumlah angka perceraian yang terjadi karena masa pandemi ini tidak 
bisa diprediksi kapan akan berhenti agar kedepannya kasus peceraian ini bisa menurun dengan berusaha secara optimal dalam melaksanakan dan menerapkan strategi yang jitu dalam mendamaikan para pihak.

\section{E. Kesimpulan}

Prosedur pelaksanaan mediasi di Pengadilan Agama Serang sudah sesuai dengan Perma No.1 Tahun 2016 tentang Prosedur Mediasi di Pengadilan dan juga menerapkan Protokol Kesehatan sesuai dengan Instruksi Presiden No. 6 Tahun 2020 tentang Peningkatan Disiplin dan Penegakan Hukum Protokol Kesehatan dalam Pencegahan dan Pengendalian Corona Virus Disease 2019. Namun jika dilihat dari segi efektivitasnya memang ada sedikit kendala pada saat melaksanakan mediasi karena harus ada jarak dan juga penggunaan masker.

Sedangkan Peran hakim mediator Pengadilan Agama Serang sejauh ini belum mampu mendamaikan para pihak yang berselisih atau berperkara, ini dapat dilihat pada laporan mediasi yang terjadi sebelum masa pandemi (tahun 2018 dan 2019) dan saat masa pandemi tahun 2020. Dengan dilihat dari jumlah perkara yang dimediasi dari tahun 2020 sebanyak 5.905 perkara, 10 perkara yang berhasil dengan kesepakatan, 8 perkara berhasil dengan pencabutan, 21 perkara berhasil dengan sebagian, 3 perkara tidak dilaksanakan dan 385 perkara yang tidak berhasil atau gagal dimediasi oleh hakim mediator Pengadilan Agama Serang. Dan juga angka perceraian yang meningkat sebanyak 3.304 kasus pasangan suami istri yang bercerai di masa pandemi 2020 dibandingkan angka perceraian pada tahun 2019 yang hanya 3.000 kasus dan tahun 2018 sebanyak 2.310 kasus perceraian. Sehingga dari data yang ada membuktikan bahwa sejauh ini hakim Pengadilan Agama Serang belum mampu mendamaikan dan menekan jumlah angka perceraian di Pengadilan Agama Serang pada Tahun 2020 di masa pandemi.

Adapun terdapat kendala yang dihadapi hakim Pengadilan Agama Serang terdiri dari beberapa faktor. Mulai dari faktor komunikasi pada saat pelaksanaan mediasi di masa pandemi dan juga para pihak yang sangat sulit untuk dipersatukan lagi, karena kebanyakan dari para pihak yang datang ke Pengadilan Agama Serang sudah memiliki niat bulat untuk bercerai sehingga hakim mediator pun sangat 
kesulitan untuk mencoba mendamaikan para pihak bersatu kembali. Jika dikaitakan dengan tiga unsur sistem hukum, yaitu struktur hukum (legal struktur), substansi hukum (legal substance) dan budaya hukum (legal culture) tidak memenuhi klasifikasi yang terdapat dalam ketiga unsur tersebut. Terutama unsur budaya hukum yang merupakan faktor yang paling dominan yang menghambat efektivitas keberhasilan mediasi sesuai dengan Perma No.1 Tahun 2016. Selain itu juga peran hakim yang tidak optimal dalam pelaksanaanya sehingga tidak bisa mendapatkan hasil yang maksimal dan belum bisa menekan jumlah angka perceraian yang terjadi pada masa pandemi ini. Di sisi lain memang ada faktor-faktor yang menjadi kendala atau hambatan hakim dalam mendamaikan para pihak yang lebih di dominasi oleh faktor internal. Seperti konflik diantara para pihak sudah berlarut-larut sehingga tidak mau mendengarkan masukan dari pihak manapun termasuk mediator, berat ringannya perkara yang dialami para pihak, keinginan yang sudah sangat kuat oleh para pihak untuk bercerai dan tidak adanya mediator dari pihak luar Pengadilan yang memiliki waktu panjang sehingga bisa membantu proses mediasi secara maksimal.

\section{Daftar Pustaka}

Abbas, Syahrizal. Mediasi Dalam Hukum Syari'ah, Hukum Adat, Dan Hukum Nasional. Jakarta: Prenada Media Group, 2009.

Ariefana, Pebriansyah. “2.000 Pasutri Di Serang Cerai Karena Suami Nganggur Selama Wabah Corona." Suarabanten.Id.

Bhaidawi, Zakiyuddin. Pendidikan Agama Berwawasan Multikultural. Jakarta: Erlangga, 2005.

Lubis, Sulaikin. Hukum Acara Peradilan Agama Di Indonesia. Jakarta: Kencana, 2005. Mahkamah Agung RI. Peraturan Mahkamah Agung Nomor 1 Tahun 2016 Tentang Prosedur Mediasi Pengadilan. Republik Indonesia, 2016.

Miftah, Ahmad Harisul, and Nurul Fazri. Wawancara Dengan Afiah- Panitera Muda Hukum Pengadilan Agama Serang. Serang, n.d.

- - - Wawancara Dengan Baehaki-Panitera. Serang, n.d.

- - - Wawancara Dengan Nurnaningsih- Hakim Pengadilan Agama Serang. Serang, 
n.d.

- - - . Wawancara Dengan Syahrul-Panitera Muda Hukum. Serang, 2021.

Republik Indonesia, Presiden. Undang-Undang Nomor 1 Tahun 1974 Tentang

Perkawinan. Indonesia, 1974.

Serang, Pemerintah Kota. “Peraturan Walikota Serang Nomor 30 Tahun 2020

Tentang Penerapan Disiplan Dan Pengedalian Corona Virus Disease 2019."

Https://Jdih.Serangkota.Go.Id. Last modified 2020. Accessed April 29, 2020.

https://jdih.serangkota.go.id.

Serang, Pengadilan Agama. "Sejarah Pengadilan Agama Serang." Pengadilan Agama

Serang. Serang, 2020. Last modified 2020. Accessed September 29, 2020.

https:/ / pa-serang.go.id/index.php?pdlg=detail\&berita=1373.

Widiyani, Rosmha. “Latar Belakang Vieus Corona, Perkembangan Hingga Isu

Terkini." News.Detik.Com. Accessed April 29, 2020.

https:/ / news.detik.com/berita/d-4943950/latar-belakang-virus-corona-

perkembangan-hingga-isu-terkini.

Instruksi Presiden No. 6 Tahun 2020 Tentang Peningkatan Disiplin Dan Penegakan

Hukum Protokol Kesehatan Dalam Pencegahan Dan Pengendalian Corona Virus

Disease 2019 (Covid-19), n.d.

Keputusan Presiden No. 12 Tahun 2020 Tentang Penetapan Bencana Non-Alam

Penyebaran Corona Virus Disease 2019 (Covid-19) Sebagai Bencana Nasional, n.d.

Peraturan Menteri Dalam Negeri (Permendagri) No. 20 Tahun 2020 Tentang Percepatan

Penanganan Corona Virus Disease 2019 Di Lingkungan Pemerintah Daerah, n.d.

Undang-Undang No. 4 Tahun 1984 Tentang Wabah Penyakit Menular, n.d. 